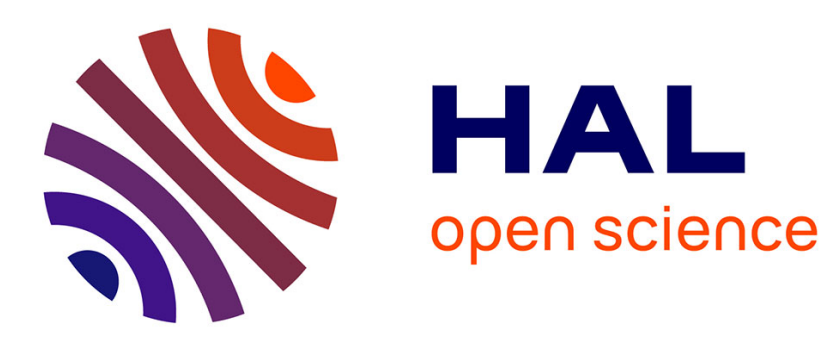

\title{
Scientific note on PCR inhibitors in the compound eyes of honey bees, Apis mellifera
}

Humberto Boncristiani, Jilian Li, Jay Evans, Jeff Pettis, Yanping Chen

\section{To cite this version:}

Humberto Boncristiani, Jilian Li, Jay Evans, Jeff Pettis, Yanping Chen. Scientific note on PCR inhibitors in the compound eyes of honey bees, Apis mellifera. Apidologie, 2011, 42 (4), pp.457-460. 10.1007/s13592-011-0009-9 . hal-01003628

\section{HAL Id: hal-01003628 \\ https://hal.science/hal-01003628}

Submitted on 1 Jan 2011

HAL is a multi-disciplinary open access archive for the deposit and dissemination of scientific research documents, whether they are published or not. The documents may come from teaching and research institutions in France or abroad, or from public or private research centers.
L'archive ouverte pluridisciplinaire HAL, est destinée au dépôt et à la diffusion de documents scientifiques de niveau recherche, publiés ou non, émanant des établissements d'enseignement et de recherche français ou étrangers, des laboratoires publics ou privés. 


\title{
Scientific note on PCR inhibitors in the compound eyes of honey bees, Apis mellifera
}

\author{
Humberto Boncristiani ${ }^{1}$, Jilian $\mathrm{LI}^{2}$, Jay D. Evans ${ }^{1}$, Jeff Pettis ${ }^{1}$, Yanping Chen ${ }^{1}$ \\ ${ }^{1}$ USDA-ARS Bee Research Lab, BARC-East Bldg. 476, Beltsville, MD 20705, USA \\ ${ }^{2}$ Institute of Apicultural Research, Chinese Academy of Agricultural Sciences, Beijing 100093, People's Republic of China
}

Received 7 October 2009 - Revised 17 June 2010 - Accepted 24 June 2010

honey bees / compound eyes / PCR inhibitor / viruses

\section{INTRODUCTION}

The advent of new molecular technologies has revolutionized the diagnosis of pathogen-caused diseases in honey bees (Apis mellifera L.). Specifically, polymerase chain reaction (PCR)-based methods are widely applicable for the detection of difficult-to-grow pathogens such as viruses. In 1995, Stoltz et al. described specific reverse transcriptasePCR (RT-PCR) primer pairs for the first detection of Kashmir bee virus infection in honey bees. Since then this methodology has offered a standard method for the detection and quantification of honey bee viruses (Stoltz et al. 1995).

Because of the high sensitivity of the PCR method, much attention has been focused on avoiding the risk of false-positive results due to carry-over contamination. Relatively less attention has been directed to the false-negative results caused by PCR inhibitors. PCR inhibitors have been reported to be present in arthropod species (Dowton and Austin 1999; Imaizumi et al. 2004; Juen and Traugott 2006) and these compounds are not removed with common DNA extraction methods. A study showed that the insect eye pigment could cause false-negative PCR results and the elimination of the PCR inhibitors was achieved by cutting out eyes prior to DNA isolation (Bextine et al. 2004). Our earlier study showed that deformed wing virus (DWV), one of the most

Corresponding author: Y. Chen,

Judy.Chen@ars.usda.gov

Manuscript editor: Monique Gauthier prevalent and common honey bee viruses, was not detected in the head of infected bees (Chen et al. 2006). However, a later publication by Genersch (2005) showed the detection of DWV in the head of infected bees when an additional step of column purification was included in the regular method of RNA extraction. The discrepancy in the results regarding the DWV infection in honey bee heads from two research groups led us to hypothesize that there was a presence of inhibitors in the honey bee compound eyes and the inhibitors could lead to suppression of the RT-PCR amplification. The present study describes the presence of PCR inhibitors in honey bee compound eyes for a standard virus detection assay and showed that the PCR inhibitors could be removed by a column-based nucleic acid purification.

\section{MATERIALS AND METHODS}

Five adult worker bees with the symptom of deformed wings were collected from a bee colony. The heads of the honey bees were cut off and put into one tube. Total RNA was extracted from the dissected honey bee heads using an RNA isolation kit (TRIzol, Invitrogen, Carlsbad, CA, USA) and dissolved in $200 \mu \mathrm{L}$ of nuclease-free water. The total was divided into two groups. One group of total RNA was left untreated and the other group was further purified using the MinElute reaction clean up kit (Qiagen, Valencia, CA, USA). The two groups of total RNA were subjected to RT-PCR for DWV detection 
A

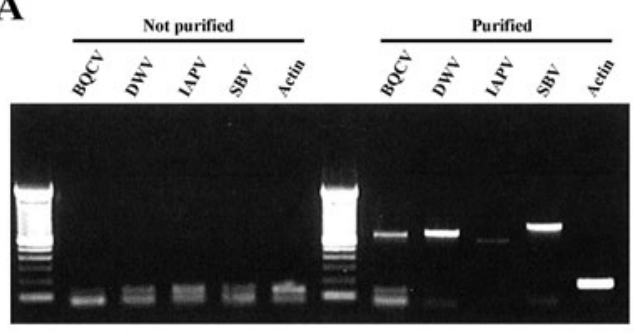

B

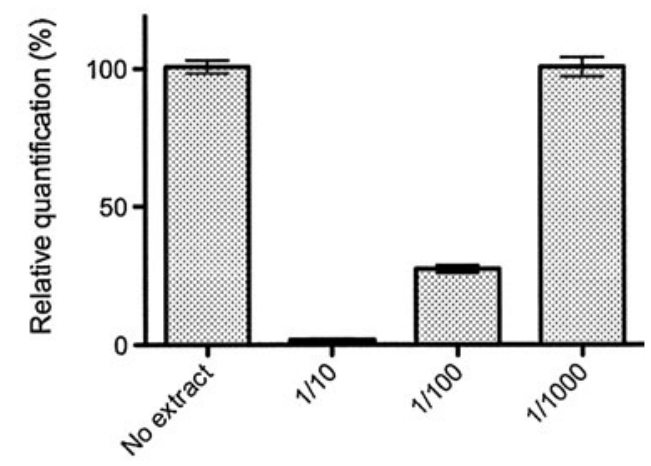

C

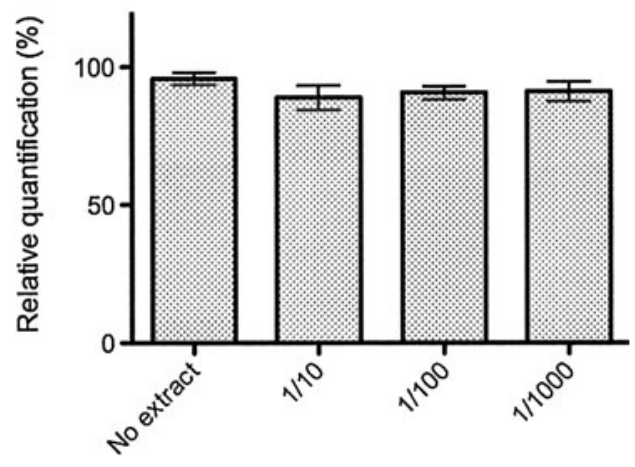

following the procedures described previously (Chen et al. 2005).

The compound eyes were dissected out from five adult worker bees with the symptom of deformed wings under light microscopy and homogenized in $50 \mu \mathrm{L}$ of nuclease-free water (Invitrogen, Carlsbad, CA) after grinding with mortar and pestle. Following a centrifugation at $10,000 \times g$ for $1 \mathrm{~min}$, the supernatant containing ocular material was collected. The eye extract was diluted as three series 10 -fold dilutions, $0.1 \times, 0.01 \times$, and $0.001 \times$ for subsequent inhibitory bioassays for determining the presence of PCR inhibitors in compound eyes.
Figure 1. a RT-PCR detection of deformed wing virus (DWV) in honey bee heads. Lane 1, $100 \mathrm{bp}$ size ladder. Lane 2, heads of DWV-infected bees. RNA was isolated from the heads of DWV-infected bees through regular Trizol extraction. Lane 3, negative control (water). Lane 4, heads of DWV-infected bees. RNA was isolated from the heads of DWV-infected bees through regular Trizol extraction followed by column purification. Lane 5, positive control (recombinant DWV plasmid DNA). b Absolute quantification of DWV in samples without a column purification step. The addition of the eye extract within the concentration range of $0.1 \times$ to $0.01 \times$ into the RNA samples could cause a dose-dependent PCR inhibition compared with the negative control. The inhibitory effect disappeared when the eye extract was diluted up to 1,000 times. The different letters on top of the bars indicate statistical differences at $P \leq 0.05$. c Absolute quantification of DWV in samples with a column purification step. Column purification could effectively remove the PCR inhibitors. There were no significant differences in DWV titers across samples with the addition of the eye extract and then cleaned with the Qiagen MinElute reaction clean up kit. The same letter on top of the bars indicates no statistical difference at $P \leq 0.05$.

Total RNA was isolated individually from five contaminated bees with the compound eye removed. The total RNA was mixed with $0.1 \times, 0.01 \times$, and $0.001 \times$ of the eye extract individually as a ratio of $1: 1$ eye extract: total RNA. Total RNA without the addition of the eye extract served as a negative control. Each mixture of RNA and eye extraction was further divided into two groups: purified or not purified on a Qiagen RNA Mini Spin Column prior to RT-PCR assay. For each group, the relative concentration of DWV in the individual bees was performed by TaqMan real time quantitative RT-PCR under established conditions (Chen et al. 2004). The DWV titers in the bees were determined based on the value of the cycle threshold $(\mathrm{Ct})$. The $\mathrm{Ct}$ values of bees mixed with the same concentration level of eye extract samples were averaged and quantification of DWV titers was performed using the absolute quantification method. The standard procedures for both absolute and comparative quantification assays require a step of normalization by a housekeeping gene which needs to fulfill the criterion of unregulated expression independent of the experimental conditions. Since PCR inhibitors could also negatively impact the amplification of any housekeeping genes, it is inaccurate and unapplicable to include a housekeeping gene for normalization. As a result, the 
titers of DWV in the bees in the present study were determined by relating the $\mathrm{Ct}$ values of unknown samples to an established standard curve. The standard curve was established by plotting the logarithm of initial quantities of the 10-fold serial dilutions of plasmid DNA with DWV insert (1 to $10^{9}$ copies) against corresponding threshold value $(\mathrm{Ct})$. The coefficient of correlation $\left(R^{2}\right)$ of the established standard curve was more than 0.98 (data not shown), indicating an excellent linear relationship between $\mathrm{Ct}$ values and the copy number and equal efficient PCR amplification over the measured dynamic range.

Statistical analysis was performed using Prism statistical software (GraphPad software, Inc.). The Fisher's least significant difference test was used to analyze significant differences of DWV titers among samples with the addition of different concentrations of eye extract. The results are expressed as the mean \pm standard deviation. Differences were considered statistically significant with $P \leq 0.05$.

\section{RESULTS AND DISCUSSION}

While DWV was not detected in total RNA isolated from heads of DWV-infected bees through regular Trizol extraction, PCR signal specific for DWV was detected in the RNA that was isolated from the same set of bees and processed through both Trizol extraction and column purification (Figure 1a), indicating the presence of PCR inhibitors which could be removed by column purification.

Quantification of DWV titers showed that the eye extract within the concentration range $0.1 \times$ to $0.01 \times$ caused a dose-dependent inhibition for the amplification of DWV, compared with the negative control without addition of the extract. While DWV titers in samples with $0.1 \times$ and $0.01 \times$ eye extract were significantly lower than that of the negative control, the inhibitory activity of the eye extract could be removed by diluting 1,000 times, as there was no significant difference in DWV concentrations between the negative control and the sample mixed with $0.001 \times$ eye extract $(P<0.05)$ (Figure $1 b)$. Column purification could effectively remove the PCR inhibitors. There was no significant difference in the titer of DWV among samples mixed with different concentration of the eye extract and then cleaned with the Qiagen MinElute reaction clean up kit (Figure 1c). These results clearly revealed that the compound eyes of honey bees contained inhibitory substances that could lead to a false negative PCR result for DWV, especially when examinations of viruses are focused on the head. However, PCR inhibitors could be minimized or effectively removed by dilution and the purification process. This is probably why viruses were still detected in most of the reports because the concentration of eye pigments was diluted when whole bees were examined.

It has been suggested that PCR inhibitors generally exert their effects through direct or indirect interactions with DNA polymerases (reviewed in Eckhart et al. 2000). When the column purification step to remove the inhibitors was carried out after reverse transcription in our study, the PCR amplification signal for the housekeeping gene $\beta$-actin could be generated (data not shown), indicating that the inhibitor did not exert an effect on reverse transcriptase. While the mechanisms underlying inhibitory effects of the eye extract of honey bees are still not very clear, precautionary steps to avoid potential PCR amplification failure should include the use of an internal control to rule out PCR inhibitors and adoption of purification methods that allow effective removal of PCR inhibitors. Follow-up studies to identify the PCR-inhibitor components present in the honey bee ocular material may be necessary for the elucidation of PCR inhibitory mechanisms of the eye extract.

\section{ACKNOWLEDGEMENTS}

The work was supported by a USDA Headquarters Postdoctoral Research Associate Program Grant.

\section{REFERENCES}

Bextine, B., Tuan, S.-J., Shaikh, H., Blua, M., Miller, T.A. (2004) Evaluation of methods for extracting Xylella fastidiosa DNA from the glassy-winged sharpshooter. J. Econ. Entomol. 97, 757-763

Chen, Y.P., Higgins, J.A., Feldlaufer, M.F. (2004) Quantitative analysis of deformed wing virus infection in the honey bee, Apis mellifera L. by real-time RT-PCR. Appl. Environ. Microbiol. 71, 436-441

Chen, Y.P., Pettis, J.S., Collins, A., Feldlaufer, M.F. (2006) Prevalence and transmission of honey bee viruses. Appl. Environ. Microbiol. 72, 606-611

Chen, Y.P., Pettis, J.S., Feldlaufer, M.F. (2005) Detection of multiple viruses in queens of the honey bee Apis mellifera L. J. Invertebr. Pathol. 90, 118-121

Genersch, E. (2005) Development of a rapid and sensitive RTPCR method for the detection of deformed wing virus, a pathogen of the honeybee (Apis mellifera). Vet. J. 169, 121123 
Dowton, M., Austin, A.D. (1999) Evolutionary dynamics of a mitochondrial rearrangement "hotspot" in the Hymenoptera. Mol. Biol. Evol. 16, 298-309

Eckhart, L., Bach, J., Ban, J., Tschachler, E. (2000) Melanin binds reversibly to thermostable DNA polymerase and inhibits its activity. Biochem. Biophys. Res. Commun. 271, 726-730

Imaizumi, K., Miyasaka, S., Yoshino, M. (2004) Quantitative analysis of amplifiable DNA in tissues exposed to various environments using competitive PCR assays. Sci. Justice 44, 199-208

Juen, A., Traugott, M. (2006) Amplification facilitators and multiplex PCR: tools to overcome PCR-inhibition in DNAgut-content analysis of soil-living invertebrates. Soil Biol. Biochem. 38, 1872-1879

Stoltz, D., Shen, X.-R., Boggis, C., Sisson, G. (1995) Molecular diagnosis of Kashmir bee virus infection. J. Apic. Res. 34, 153-160 